\title{
Adoption of environmental innovations: Analysis from the Waipara wine industry
}

\author{
Sharon L. Forbes*, Ross Cullen, Rachel Grout \\ Commerce Faculty, Lincoln University, Lincoln, PO Box 85084, Christchurch 7647, New Zealand
}

Available online 14 March 2013

\begin{abstract}
The Greening Waipara Project developed and introduced a number of ecologically and environmentally-focused practices to the Waipara vineyards and wineries of North Canterbury, New Zealand. This paper describes the practices that were introduced to the Waipara wine industry as part of the Greening Waipara Project and evaluates the adoption of these environmental innovations by wine businesses. In addition, this paper examines the sustainability of these practices in terms of business costs and benefits. Data for the evaluation was obtained from a survey of vineyards and wineries in the Waipara region. Results reveal that adoption of the environmental innovations is relatively low and varies across wine growing properties. Furthermore, the costs associated with the innovations tend to outweigh the benefits gained by the businesses.
\end{abstract}

(C) 2013 UniCeSV, University of Florence. Production and hosting by Elsevier B.V. Open access under CC BY-NC-ND license.

Keywords: Adoption; Environment; Innovations

\section{Introduction}

Feder and Umali (1993) noted that as environmental issues in agricultural businesses have gained attention, increasing focus is being applied to examining the adoption of environmental innovations. Clearly the need for the adoption of environmental practices and innovations is greater than ever, especially in agriculture where the level and severity of environmental problems continue to rise. Conventional wine production practices result in similar environmental issues to those incurred in other agricultural businesses, including groundwater depletion, water pollution, effluent run-off, toxicity of pesticides, fungicide and herbicide use, habitat destruction, and loss of natural biodiversity. This study adds to the current knowledge

\footnotetext{
${ }^{*}$ Corresponding author. Tel.: +64 33218301.

E-mail addresses: sharon.forbes@lincoln.ac.nz (S.L. Forbes), ross.cullen@lincoln.ac.nz (R. Cullen), rachel.grout@lincoln.ac.nz (R. Grout).

Peer review under responsibility of Wine Economics and Policy.

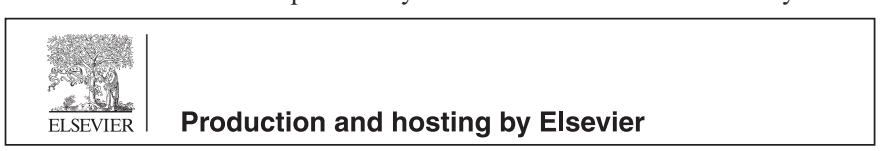

regarding the adoption of environmental innovations, specifically in the wine industry.

Waipara is a rapidly growing wine region located north of Christchurch on New Zealand's South Island. The Greening Waipara Project began in 2005 and around 32 of the Valley's vineyards and wineries are now participating. The Project stemmed from initiatives by Lincoln University's Bio-Protection Research Centre, the Waipara Valley Winegrowers Association, the Hurunui District Council and Landcare Research to make use of 'nature's free services'. In addition, the Greening Waipara Project was initiated because the Waipara wine region is less well known than other high profile wine regions within New Zealand and one aim was to give Waipara wines a clear point of difference. The Project has developed and introduced seven environmental innovations that could be implemented by wine companies in the Waipara region. These practices are based on utilising nature's services in areas including pollination, biological control of pests, weed suppression, improved soil quality, filtering of wastes and conservation of native species. The Project has issued brochures which claim that the adoption of the practices will reduce agrichemical and labour costs, support ecotourism, and help with the marketing of Waipara wines. 
This paper examines how many of the vineyards and wineries have adopted the innovations and the implications of the implemented practices in terms of business costs and benefits. The remainder of this paper is structured as follows. Firstly, details are provided of the seven environmental innovations developed by the Greening Waipara Project. A review of the environmental innovation literature includes both a focus on agriculture in general and a specific focus on the wine industry. Details of the research method adopted in this study then follow. Presentation of the results is followed by the discussion and conclusions.

\section{Greening Waipara environmental innovations}

The Greening Waipara Project developed and introduced a total of seven environmental innovations for Waipara vineyards and wineries to adopt. One of these innovations was based on the use of biological control practices to control leafrollers (Planotortrix and Ctenopseustis genera) in vineyards. The wine industry in New Zealand has identified leafrollers as an important insect pest as they cause leaf, flower and fruit damage, and open berries to infection by the fungus Botrytis cinerea (Berndt et al.,2006). Crop losses attributed to leafroller damage in the New Zealand wine industry have been estimated to cost up to NZ\$360/ha in a dry year and significantly more in wetter seasons (Lo and Murrell 2000). The usual practice to control leafrollers in vineyards is the application of a broad-spectrum insecticide. The Greening Waipara Project innovation used inter-row plantings of flowering plants (e.g. buckwheat) to attract parasitoid wasps, a natural enemy of leafrollers, into the vineyards. Research at trial sites revealed that adding annual flowering plants, such as buckwheat, into a vineyard ecosystem increased the impact of parasitoids on leafrollers (Berndt et al., 2006).

Another innovation introduced by the Greening Waipara Project involved the plantings of native groundcovers to control under vine weeds and thus reduce the need for herbicide applications. Other benefits that were expected to arise from these plantings included increasing the diversity and abundance of beneficial insects, reduced runoff and improved soil structure. A third innovation focused on the restoration of natural habitats in and around vineyards and wineries. The aim of this innovation was for the native plant species to assist with the conservation of native fauna and flora, as well as soil retention, weed suppression and eco-tourism. The Project has planted more than 20,000 native plants into the Waipara Valley. Other innovations developed by the Greening Waipara Project included the use of mulches (i.e. pea straw, linseed straw and grass clippings) under vines to manage Botrytis, improvements in the filtering of winery waste water, and the development of windbreaks through hedging.
The seventh innovation involved the introduction of Biodiversity Trails on selected winery properties. These Trails were established to provide winery customers with a unique and informing experience at Waipara wineries. Each Trail was developed close to a tasting room or restaurant and led the visitor through areas of vines and native plants, and included information boards where they could learn more about biodiversity and Greening Waipara.

\section{Adoption of environmental innovations}

Mosher (1978) formally defined adoption as the process through which a person is exposed to, considers, and finally rejects or accepts and practices an innovation. More recently, Rogers (2003) defined adoption as the implementation of transferred knowledge about a technological innovation. Adoption can thus be thought of as the final stage of the technology transfer process. Adoption occurs when a person has decided to make full use of a new technological innovation as the best way to address a need (Rogers, 2003). This would suggest that wine producers with the greatest need to resolve or control a problem would be most likely to adopt a related innovation. Feder and Umali (1993, p. 216) defined an innovation as "a technological factor that changes the production function and regarding which there exists some uncertainty, whether perceived or objective (or both)".

The characteristics of an individual innovation influence the rate of its adoption. These characteristics are the levels of relative advantage, compatibility, complexity, trialability and observability (Rogers, 2003). Relative advantage can be measured economically, but can also include advantages in terms of prestige, convenience or satisfaction. Compatibility is achieved when an innovation is consistent with existing values, past experiences and the needs of the potential adopters. Complexity is the degree to which an innovation is difficult to understand, implement and maintain. Trialability relates to whether the innovation can be experimented with on a limited basis, whilst observability is the degree to which the results of the innovation are visible to others. Prior research suggests there are numerous factors which influence whether an agricultural innovation is adopted or not, and many of these can be seen to relate to the innovation characteristics developed by Rogers (2003).

Vanclay and Lawrence (1994) suggested that there are fundamental differences between commercial innovations and environmental innovations which affect adoption by agriculturists. Sassenrath et al. (2008) also noted that some innovations are driven by a desire to improve yields, whilst others are concerned for the environment. Environmental innovations are those which focus on improvements to land management. Although environmental innovations may result in some direct economic benefits, the costs associated with the adoption of these 
innovations are often high and are typically borne by the individual farmer. In contrast, commercial innovations are focused on increased productivity of agricultural activities and the benefits arising from adoption typically outweigh the costs. The authors argue that as the costs of adopting environmental innovations may outweigh the commercial benefits for an individual farmer then adoption will not be in the farmer's economic interest and the result will be large-scale non-adoption (Vanclay and Lawrence, 1994). This argument would appear to hold true, as Buttel et al. (1990) reported that the environmental innovations in agriculture that have been most widely adopted are those which are commercially oriented, such as minimum tillage. Clearly, the profit motive is one of a range of factors which can influence the adoption of new technologies and practices in agriculture.

A variety of factors have been found to influence the adoption of agricultural innovations. Sassenrath et al. (2008) noted that the adoption of innovations by agriculturists is an interaction between a range of external and internal factors, such as political and social pressures and monetary constraints. Whilst there is little doubt that agriculturists seek increased profitability through innovations, they also tend to be quite risk-averse. Agricultural innovations which reduce risk and are simple to establish are thus likely to be those which are most readily adopted by farmers (Sassenrath et al., 2008). A review of agricultural literature revealed that adoption of innovations by farmers is generally related to the process of learning about the innovation, the relative advantage of the innovation over existing practices and the ease of innovation trialability (Cullen et al., 2008). Vosti et al. (1998) stated that socioeconomic aspects of a technological innovation would influence its adoption. These studies again highlight the importance of commercial or economic factors. Similarly, Feder and Umali (1993) noted that the factors which constrain the adoption of agricultural innovations included lack of credit, limited access to information and inputs, and inadequate infrastructure. Australian researchers have developed a tool for predicting an agricultural innovation's likely peak extent of adoption and the likely timeframe for reaching that peak (Kuehne et al., 2011). The authors suggest that multiple variables in the tool sit in four quadrants: (1) populationspecific influences on the ability to learn about the innovation; (2) relative advantage for the population; (3) learnability characteristics of the innovation; and (4) relative advantage of the innovation. Variables that reside within these quadrants include group involvement, skills and knowledge, awareness, trialability, innovation complexity, observability, profit orientation, environmental orientation, risk orientation, upfront cost, profit benefit, ease and convenience, and environmental costs and benefits (Kuehne et al., 2011).

Several factors have also been found to influence the adoption of environmental innovations by agriculturists.
Studies that have examined the factors which influence the adoption of biological pest control practices have suggested that adoption is moderated by the perception of risk (Griffiths et al., 2008; Shadbolt, 2005). In general, the adoption of biological pest control practices by agriculturists has been found to be quite limited (Falconer and Hodge, 2000; Pietola and Lansink, 2001). Other factors which were found to influence the adoption of biological pest control innovations include the efficacy of the innovation, the possibility of price premiums in the marketplace, and reduced expenditure on agrichemicals and labour (Griffiths et al., 2008; Shadbolt, 2005). Other studies have reported that costs are the dominant reason why agriculturists do not adopt environmentally sustainable practices (Curtis and Robertson, 2003; Rhodes et al., 2002). A study of New Zealand dairy farmers and their propensity to adopt sustainable management practices provides a summation of the factors frequently mentioned in the adoption literature. Besswell and Kaine (2005) reported that farmers recognised the environment was important, but they were not convinced that some of the practices being promoted as environmentally friendly were actually practical. Adoption was found to depend primarily upon the farmer's perception of the benefits that would arise, and these related to the commercial and practical realities of the innovation to the farmer.

The previous sections summarise literature relating to the adoption of agricultural innovations in general and environmental agricultural innovations in particular. Other studies have examined the factors which drive the adoption of sustainable, ecological or environmental practices within the wine industry. The identified drivers for adoption of environmental innovations include the attitudes and norms of the manager (Marshall et al., 2010), increased profits (Hughey et al., 2004), and improved environmental performance (Delmas et al., 2006). Marketing reasons, such as gaining a competitive advantage, creating product differentiation, and improved or maintained market access, have also been found to drive the adoption of environmental practices in the wine industry (Adrian and Dupre, 1994; Bhaskaran et al., 2006; Marshall et al., 2005; Molla-Bauza et al., 2005; Nowak and Washburn, 2002).

The literature review above highlights the varying reasons why agriculturists might adopt innovations. In particular, previous research suggests that farmers will be less likely to adopt environmental innovations if they will not result in economic benefits. The Greening Waipara Project claimed that adoption of the environmental innovations will reduce costs and assist with marketing Waipara wines. The literature would support the idea that adoption of the innovations amongst Waipara wine companies would be high as the Project has stated that economic benefits would be gained. The first research question examined by this study is thus: What has been the level of adoption of the seven environmental innovations by Waipara vineyards and wineries? 


\section{Business impact of environmental innovations}

The economic impact arising from the implementation of environmental innovations is a key factor for agriculturists to consider, and one which has not been extensively explored in the literature. In their seminal paper, Constanza et al. (1997) suggested that ecosystem services are not fully captured or adequately quantified in traditional economic analysis; they estimated that the value of biological control of pests globally was US $\$ 417$ billion per year. Pimentel et al. (1997) estimated that services arising from biodiversity in the United States contributed $\$ 319$ billion each year, whilst globally the benefits amounted to \$2929 billion annually. In addition, Pimentel et al. (1997) reported that the growing eco-tourism industry contributed between US\$0.5 and US\$1 trillion per year to the global economy. Dyllick and Hockerts (2002) noted that although the value of ecosystem services is quite considerable, this value is not necessarily well understood.

Similarly, Cullen et al. (2008) stated that economic assessments of biological pest control programmes are rarely conducted and therefore poorly understood. Pannell et al. (2006, p. 1409) stated that "... the benefits and costs of some conservation practices are not clearly observable" and hence decision making regarding adoption of these innovations by farmers may be impeded. A few previous studies have provided some support for small economic savings being gained through the adoption of biological pest control programmes (Kellermann, 2007; Thomas et al., 1991), whilst others have reported that these programmes are not cost effective for farmers (Schmidt et al., 2007).

Research from the wine industry also reports mixed results in terms of the costs and benefits relating to the adoption of environmental, ecological or sustainable practices. Delmas et al. (2006) reported that increased costs of $10-15 \%$ can be expected in the first four years of adopting sustainable vineyard practices. The study also reported an increase in labour costs of $30 \%$ due to planning, preparation and maintenance. Conversely, Marshall et al. (2010) reported that the adoption of environmental practices in the wine industry would result in economic benefits through reduced consumption of raw materials, increased productivity, decreased energy consumption and waste reductions. Hughey et al. (2004) suggested that environmental strategies are becoming an important marketing tool in international markets where consumers are more environmentally aware. It has also been suggested that wine businesses can gain price premiums through the adoption of environmental practices (Adrian and Dupre, 1994; Fairweather et al., 1999). The California wine industry has invested time and money to develop sustainable production techniques; this industry seeks to increase the market value and perceived quality of their wines through branding it as sustainable (Warner, 2007).

The literature reports mixed results in terms of the business impact arising from the adoption of environmental innovations in agriculture. The second research question examined in this study is thus: What impact has the implementation of the seven environmental innovations had on economic, marketing and operational factors at the Waipara vineyards and wineries?

\section{Method}

This study gathered data via a self-completed, structured questionnaire mailed to all of the vineyards and wineries in Waipara in early December 2009. Follow-up postcards were sent to the vineyards and wineries in early 2010 in order to increase the response rate. A total of 14 companies responded to the questionnaire, resulting in an acceptable response rate of $44 \%$. Five of the 14 companies in the sample were vineyards without attached wineries; the largest vineyard was approximately 450 ha in size and the next largest was just 55 ha. Of the nine wineries, eight had annual wine sales of less than 200,000 1 . The sampled wineries thus reflect the nature of the New Zealand wine industry as a whole, which is comprised predominantly of small producers. Most of the companies noted that they had been involved with the Greening Waipara Project for two or three years and had joined for a number of reasons, including the planting of native species and the provision of shelters for birds. One respondent noted that they had no particular reason for joining. Although the sample is small in number, there is no reason to believe that it is not representative of the Waipara wine companies in terms of adoption of the environmental innovations. The authors received anecdotal evidence from an Analyst employed by the Greening Waipara Project about low rates of adoption, and this corresponds with our results.

The questionnaire began with general questions that were used to categorise the winery or vineyard operation. Section B examined whether the company had implemented a Biodiversity Trail or had any desire to do so. Respondents indicated which of the innovations they had implemented in Section C of the questionnaire and subjectively rated the effectiveness of each implemented innovation using a 4-point likert scale (i.e. 'ineffective', 'somewhat effective', 'very effective' and 'unsure'). The final section asked each respondent to indicate what impact (i.e. increase, decrease or no effect) the adoption of each innovation had on their business in terms of various listed factors (e.g. labour costs, domestic sales, and water use).

\section{Results and discussion}

The first research question examined the level of adoption of the seven environmental innovations by Waipara vineyards and wineries. Table 1 indicates the number of companies that have adopted the seven innovations introduced by the Greening Waipara Project and each respondent's rating of the effectiveness of each implemented innovation. 
Table 1

Adoption of the environmental innovations.

\begin{tabular}{|c|c|c|c|c|c|}
\hline \multirow[t]{2}{*}{ Innovation } & \multicolumn{4}{|l|}{ Adopted } & \multirow{2}{*}{$\begin{array}{l}\text { Not } \\
\text { Adopted }\end{array}$} \\
\hline & Ineffective & $\begin{array}{l}\text { Somewhat } \\
\text { effective }\end{array}$ & $\begin{array}{l}\text { Very } \\
\text { effective }\end{array}$ & Unsure & \\
\hline $\begin{array}{l}\text { Inter-row plantings } \\
\text { to prevent leaf } \\
\text { rollers }\end{array}$ & 1 & 1 & & & 12 \\
\hline $\begin{array}{l}\text { Under vine weed } \\
\text { control through } \\
\text { native groundcovers }\end{array}$ & & 1 & & & 13 \\
\hline $\begin{array}{l}\text { Windbreaks through } \\
\text { hedging }\end{array}$ & & 2 & & & 12 \\
\hline $\begin{array}{l}\text { Winery waste water } \\
\text { filtering }\end{array}$ & & 1 & & & 13 \\
\hline $\begin{array}{l}\text { Conservation of } \\
\text { native fauna and } \\
\text { flora (native } \\
\text { plantings) }\end{array}$ & 2 & 6 & 2 & 1 & 3 \\
\hline $\begin{array}{l}\text { Botrytis } \\
\text { management } \\
\text { through mulching }\end{array}$ & & & 1 & & 13 \\
\hline Biodiversity Trail & & 1 & & & 13 \\
\hline
\end{tabular}

The results in Table 1 indicate there was a very low level of adoption for all the innovations except for the conservation of native fauna and flora. One respondent commented that they had been a member of the Greening Waipara programme for two years and had not implemented any of the innovations. Only one of the 14 respondents had implemented a Biodiversity Trail, although five respondents expressed an interest in building one in the future. The innovations to manage under vine weeds through native groundcovers, winery waste water filtering, and Botrytis management through mulching had also only been implemented by a single respondent.

The results in Table 1 suggest that the Greening Waipara innovations may not have delivered clear economic benefits to adopters, in line with previous literature that has reported the low adoption rates by farmers of environmental innovations that lack economic benefits (Buttel et al., 1990; Sassenrath et al., 2008). Rogers (2003) stated that adoption will occur when there is a need to address. The low level of adoption across six of the Greening Waipara innovations would thus also suggest that these innovations were not addressing needs that were of serious importance to decision makers. The low adoption rates also infer that the innovations did not have the desired levels of relative advantage, compatibility, complexity, trialability and observability (Rogers, 2003).

The innovation that was most widely adopted was that of conservation of native fauna and flora through native plantings. It should be noted that this innovation did not require the vineyards and wineries to make any contribution in terms of financial or labour inputs; the Greening Waipara Project paid for the thousands of native plants that were planted around the participating properties and supplied the labour to plant these. It could be argued that the uptake of this innovation has been greatest because the companies had not been required to make any financial investment or contribution. As previous studies have reported that costs are a major reason for the non-adoption of environmental practices (Curtis and Robertson, 2003; Rhodes et al., 2002), the high adoption rate of the native plantings innovation is likely to relate to the low costs involved. In line with Rogers (2003) study, it could be argued that adoption of this innovation has provided a relative advantage, compatibility and observability with no level of risk to the decision maker. Risk-averse agriculturists will more readily adopt low risk innovations (Griffiths et al., 2008; Sassenrath et al., 2008; Shadbolt, 2005); thus the low risk native planting innovation was the one which was most likely to be widely adopted.

Whilst adoption has been generally low, Table 1 also indicated that where the innovations had been implemented their overall level of effectiveness has been quite poor. Further research would be necessary to fully understand the reasons behind the effectiveness ratings that the respondents have provided, although Table 2 may provide some of the answers. Table 2 illustrates the impact (i.e. Increase, No effect or Decrease) that the adopted innovations have had on various economic, marketing and operational factors at each company.

The majority of the adopted innovations have had little or no effect on the companies in terms of economic, operational or marketing factors (see Table 2). Indeed, the windbreaks innovation has had no effect at all on the two businesses that had adopted the innovation, and nor did the waste water filtering innovation have any effect on the single business that had adopted it.

From an economic perspective, several respondents noted that some of the innovations resulted in increased costs for companies. For instance, the adoption of some of the innovations has led to increased labour and vineyard floor management costs, and has introduced additional costs in terms of maintaining the implemented innovations. On a positive note, some of these increased costs may be offset by the reduced agrichemical costs which some respondents noted they gained as a result of adopting some of the innovations. One respondent noted that they did not have the necessary funds to purchase the equipment they would need in order to implement the inter-row plantings innovation. Another respondent commented that they have to water the new native plants and this incurs them an extra cost in terms of labour and water. They also noted that they have not adopted any of the other innovations as their understanding was that costs would increase by too much for their business. The results of this study provide support for previous research which has suggested that the adoption of environmental practices will increase costs (Delmas et al., 2006; Schmidt et al., 2007), as well as partial support for literature which has reported that adoption can lead to economic benefits (Kellerman, 2007; Marshall et al., 2010; Thomas et al., 1991). 
Table 2

Business impact of adopted innovations.

\begin{tabular}{|c|c|c|c|c|c|c|c|c|c|c|c|c|c|c|c|c|c|c|c|c|c|}
\hline & \multicolumn{3}{|c|}{$\begin{array}{l}\text { Inter-row plantings to } \\
\text { prevent leaf rollers }\end{array}$} & \multicolumn{3}{|c|}{$\begin{array}{l}\text { Under vine weed control } \\
\text { through native groundcovers }\end{array}$} & \multicolumn{3}{|c|}{$\begin{array}{l}\text { Windbreaks through } \\
\text { hedging }\end{array}$} & \multicolumn{3}{|c|}{$\begin{array}{l}\text { Winery waste water } \\
\text { filtering }\end{array}$} & \multicolumn{3}{|c|}{$\begin{array}{l}\text { Conservation of native } \\
\text { fauna and flora }\end{array}$} & \multicolumn{3}{|c|}{$\begin{array}{l}\text { Botrytis management } \\
\text { through mulching }\end{array}$} & \multicolumn{3}{|c|}{ Biodiversity Trail } \\
\hline & Increase & $\begin{array}{l}\text { No } \\
\text { effect }\end{array}$ & Decrease & Increase & $\begin{array}{l}\text { No } \\
\text { Effect }\end{array}$ & Decrease & Increase & $\begin{array}{l}\text { No } \\
\text { effect }\end{array}$ & Decrease & Increase & $\begin{array}{l}\text { No e } \\
\text { ffect }\end{array}$ & Decrease & Increase & $\begin{array}{l}\text { No } \\
\text { effect }\end{array}$ & Decrease & Increase & $\begin{array}{l}\text { No } \\
\text { effect }\end{array}$ & Decrease & Increase & $\begin{array}{l}\text { No } \\
\text { effect }\end{array}$ & Decrease \\
\hline \multicolumn{22}{|l|}{ Economic factors } \\
\hline Cost of labour & 1 & 1 & & 1 & & & & 2 & & & 1 & & 5 & 6 & & & 1 & & 1 & & \\
\hline Cost of agrichemicals & & & 2 & & & 1 & & 2 & & & 1 & & & 11 & & & & 1 & & 1 & \\
\hline Cost of vineyard floor management & 1 & 1 & & 1 & & & & 2 & & & 1 & & & 11 & & & 1 & & 1 & & \\
\hline Cost to maintain implemented practices & & 2 & & 1 & & & & 2 & & & 1 & & 4 & 7 & & & 1 & & 1 & & \\
\hline \multicolumn{22}{|l|}{ Marketing factors: } \\
\hline Wine price & & 2 & & & 1 & & & 2 & & & 1 & & & 11 & & & 1 & & & 1 & \\
\hline Customer demand & & 2 & & & 1 & & & 2 & & & 1 & & & 11 & & & 1 & & & 1 & \\
\hline Advertising/ promotions expenditure & & 2 & & & 1 & & & 2 & & & 1 & & & 11 & & & 1 & & & 1 & \\
\hline Cellar door sales & & 2 & & & 1 & & & 2 & & & 1 & & & 11 & & & 1 & & & 1 & \\
\hline Domestic sales & & 2 & & & 1 & & & 2 & & & 1 & & & 11 & & & 1 & & & 1 & \\
\hline International sales & & 2 & & & 1 & & & 2 & & & 1 & & & 11 & & & 1 & & & 1 & \\
\hline Access into new domestic markets & 1 & 1 & & 1 & & & & 2 & & & 1 & & & 11 & & & 1 & & 1 & & \\
\hline Access into new international markets & 1 & 1 & & 1 & & & & 2 & & & 1 & & & 11 & & & 1 & & 1 & & \\
\hline Communication with Waipara wineries & & 2 & & & 1 & & & 2 & & & 1 & & 1 & 10 & & & 1 & & & 1 & \\
\hline Communication with Waipara vineyards & 1 & 1 & & 1 & & & & 2 & & & 1 & & 1 & 10 & & & 1 & & 1 & & \\
\hline \multicolumn{22}{|l|}{ Operational factors: } \\
\hline Need for vineyard bird control & & 2 & & & 1 & & & 2 & & & 1 & & & 11 & & & 1 & & & 1 & \\
\hline Need for vineyard pest control & & 1 & 1 & & & 1 & & 2 & & & 1 & & & 11 & & & 1 & & & & 1 \\
\hline Level of vineyard soil erosion & 1 & 1 & & & & 1 & & 2 & & & 1 & & & 11 & & & 1 & & & & 1 \\
\hline Level of water use (irrigation) & & 2 & & 1 & & & & 2 & & & 1 & & 3 & 8 & & & 1 & & & 1 & \\
\hline Grape quality & & 2 & & & 1 & & & 2 & & & 1 & & & 11 & & 1 & & & 1 & & \\
\hline Wine quality & & 2 & & & 1 & & & 2 & & & 1 & & & 11 & & 1 & & & & 1 & \\
\hline Yield per hectare & & 2 & & & 1 & & & 2 & & & 1 & & & 11 & & & 1 & & & 1 & \\
\hline
\end{tabular}


In terms of marketing, none of the adopted innovations has had an effect on important aspects such as the wine price, consumer demand, cellar door sales, domestic sales, or international sales. Some respondents noted that adoption of innovations such as inter-row plantings, under vine weed control, and a Biodiversity Trail had increased their access into new domestic and international markets. This result supports the previous study of Hughey et al. (2004) who had suggested that environmental practices are an important marketing tool for New Zealand wineries in international markets. Whilst some companies have included a comment about the innovations on the back label of their bottles, it should be noted that there is no standardised Greening Waipara symbol or logo that companies can include on their front labels. The lack of marketing benefits to arise from the innovations is thus likely attributable to poor consumer awareness and recognition.

From an operational perspective, the innovations have had no effect on yield per hectare, but in some instances they have resulted in an increased level of water use. There were mixed results reported for both wine quality and the level of vineyard soil erosion. Overall, adoption of the innovations has generally had little effect on operational factors. Again, the low adoption rate may reflect the lack of operational benefits; this suggestion is supported by previous research in the New Zealand dairy industry which suggests that farmers will primarily consider commercial and practical realities when deciding whether to adopt environmental practices (Beswell and Kaine, 2005).

Preliminary findings suggest that the level of economic cost associated with many of the Greening Waipara Project innovations may outweigh the economic benefits. However, in many instances, the innovations have been implemented by winery and vineyard owners who are personally committed to preservation of the environment and are prepared to pay an economic cost in order to support these beliefs. Whilst the literature notes that the costs of environmental innovations are often borne by the individual farmer, Vanclay and Lawrence (1994) also noted that large-scale non-adoption will occur if the costs of the environmental innovation do not outweigh the commercial benefits for the farmer; this appears to be what the results of this study indicate has happened with non-adoption of the Greening Waipara practices. Personal beliefs alone may not be enough to ensure that the implemented innovations will continue to exist given the present difficult financial times faced by wine companies. There is no doubt that the innovations introduced by the Greening Waipara Project can have a positive effect on the sustainability of the environment; however, if they are not also sustainable at a business level they are unlikely to be implemented or maintained.

\section{Conclusion}

This research has studied the adoption of environmental innovations in the Waipara wine growing region and found that of the seven innovations, only one has been widely adopted. The adoption of that innovation, conservation of native flora and fauna, has been heavily subsidised by the Greening Waipara Project and its adoption has been almost costless and risk free for wine growers. In addition, the success of this innovation was relatively easy for wine companies to 'measure'; the initial plantings and subsequent growth of native habitat areas is a particularly visual innovation for both staff and other stakeholders to see and enjoy. The performance of some of the other innovations was not generally so easy for companies to measure.

The adoption of innovations in agriculture has been widely studied. It is obvious that agricultural businesses need to focus on economic viability in order to survive. Environmental innovations have been developed for many types of agriculture including the wine industry, and they will be considered for adoption only if they bring an environmental and economic advantage. It is clear that the Greening Waipara Project promoted the seven innovations they developed based on environmental or ecological improvements. The low level of adoption of the other six environmental innovations, together with comments provided by industry respondents, indicates that the innovations do not provide a sufficient economic advantage to businesses. Their non-adoption is consistent with the results from other New Zealand and international environmental innovation adoption research. The results of this study suggest that economic, marketing or operational factors were not considered by the Project and the lack of resulting benefits or increasing costs in these areas are instrumental in the low levels of adoption reported herein. This study advocates that economic, marketing and operational factors are considered during the development and promotion of future environmental innovations.

This leads to an interesting proposition for further research. It would be useful to examine whether environmental innovations which have been developed with economic, marketing and operational factors in mind achieve a higher adoption rate than those innovations which focus on environmental improvement alone.

\section{Acknowledgements}

The authors wish to thank the Lincoln University Internal Research Fund for financial support of this research.

\section{References}

Adrian, M., Dupre, K., 1994. The environmental movement: a status report and implications for pricing. SAM Advanced Management Journal 59 (2), 35-40.

Berndt, L.A., Wratten, S.D., Scarratt, S.L., 2006. The influence of floral resource subsidies on parasitism rates of leafrollers (Lepidoptera: Tortricidae) in New Zealand vineyards. Biological Control 37, 50-55.

Beswell, D., Kaine, G., 2005. Adoption of environmental best practice amongst dairy farmers. In: Proceedings of the 11th Annual Conference of the New Zealand Agricultural and Resource Economics Society Inc., 26-27 August, Nelson. 
Bhaskaran, S., Polonsky, M., Cary, J., Fernandez, S., 2006. Environmentally sustainable food production and marketing. British Food Journal 108 (8), 677-690.

Buttel, F.H., Larson, O.F., Gillespie, G.W., 1990. The Sociology of Agriculture. Greenwood Press, New York.

Constanza, R., d'Arge, R., de Groot, R., Farber, S., Grasso, M., Hannon, B., Limburg, K., Naeem, S., O’Neill, R.V., Paruelo, J., Raskin, R.G., Sutton, P., van den Belt, M, 1997. The value of the world's ecosystem services and natural capital. Nature 287, 253-260.

Cullen, R., Warner, K.D., Jonsson, M., Wratten, S.D., 2008. Economics and adoption of conservation biological control. Biological Control 45, 272-280.

Curtis, A., Robertson, A., 2003. Understanding landholder management of river frontages; the Goulburn Broken. Ecological Management and Restoration 4 (1), 45-54.

Delmas, M.A., Doctori-Blass, V., Shuster, K., 2006. Caego vinegarden: how green is your wine? UC Santa Barbara: Donald Bren School of Environmental Science and Management Program on Governance for Sustainable Development. Available from: 〈http://www.escholarship. org/uc/item/5k657745 >.

Dyllick, T., Hockerts, K., 2002. Beyond the business case for corporate sustainability. Business Strategy and the Environment 11, 130-141.

Fairweather, J.R., Campbell, H.R., Manhire, J., 1999. The "Greening" of the New Zealand Wine Industry: Movement Towards the Use of Sustainable Management Practices. Department of Anthropology, University of Otago, Dunedin.

Falconer, K., Hodge, I., 2000. Using economic incentives for pesticide usage reductions: responsiveness to input taxation and agricultural systems. Agricultural Systems 63, 175-194.

Feder, G., Umali, D.L., 1993. The adoption of agricultural innovations: a review. Technological Forecasting and Social Change 43, 215-239.

Griffiths, G.J.K., Holland, J.M., Bailey, A., Thomas, M.B., 2008. Efficacy and economics of shelter habitats for conservation biological control. Biological Control 45, 200-209.

Hughey, K.F.D., Tait, S.V., O'Connell, M.J., 2004. Qualitative evaluation of three environmental management systems in the New Zealand wine industry. Journal of Cleaner Production 13, 1175-1187.

Kellermann, J.L., 2007. Ecological and Economic Services Provided by Birds on Jamaican Blue Mountain Coffee Farms. MSc Thesis Humboldt State University, California, USA.

Kuehne, G., Llewellyn, R., Pannell, D., Wilkinson, R., Dolling, P., Ewing, M., 2011. ADOPT: a tool for predicting adoption of agricultural innovations. In: Proceedings of the 55th Annual National Conference of the Australia Agricultural \& Resources Economics Society, 8-11 February, Melbourne.

Lo, P.L., Murrell, V.C., 2000. Time of leafroller infestation and effect on yield in grapes. New Zealand Plant Protection 53, 173-178.

Marshall, R.S., Akoorie, M.E.M., Hamann, R., Sinha, K., 2010. Environmental practices in the wine industry: an empirical application of the theory of reasoned action and stakeholder theory in the United States and New Zealand. Journal of World Business 45 (4), 405-414.
Marshall, R.S., Cordano, M., Silverman, M., 2005. Exploring individual and institutional drivers of proactive environmentalism in the US wine industry. Business Strategy and the Environment 14 (2), 92-109.

Molla-Bauza, B.B., Martinez, L.M., Poveda, A.M., Perez, M.R., 2005. Determination of the surplus that consumers are willing to pay for an organic wine. Spanish Journal of Agricultural Research 3 (1), 43-51.

Mosher, A.T., 1978. An Introduction to Agricultural Extension. Singapore University Press, Singapore.

Nowak, L.I., Washburn, J.H., 2002. Building brand equity: consumer reactions to proactive environmental policies by the winery. International Journal of Wine Marketing 14 (3), 5-19.

Pannell, D.J., Marshall, G.R., Barr, N., Curtis, A., Vanclay, F., Wilkinson, R., 2006. Understanding and promoting adoption of conservation practices by rural landholders. Australian Journal of Experimental Agriculture 46, 1407-1424.

Pietola, K.S., Lansink, A.O., 2001. Farmer response to policies promoting organic farming techniques in Finland. European Review of Agricultural Economics 28, 1-15.

Pimentel, D., Wilson, C., McCullum, C., Huang, R., Dwen, P., Flack, J., Tran, Q., Saltman, T., Cliff, B., 1997. Economic and environmental benefits of biodiversity. Bioscience 47 (11), 747-757.

Rhodes, H.M., Leland, L.S., Niven, B.E., 2002. Farmers, streams, information and money: does informing farmers about riparian management have any effect? Environmental Management 30 (5), 665-677.

Rogers, E.M., 2003. Diffusion of Innovations. The Free Press, New York.

Sassenrath, G.F., Heilman, P., Luschei, E., Bennett, G.L., Fitzgerald, G., Klesius, P., Tracy, W., Williford, J.R., Zimba, P.V., 2008. Technology, complexity and change in agricultural production systems. Renewable Agriculture and Food Systems 23 (4), 285-295.

Schmidt, N.P., O’Neal, M.E., Singer, J.W., 2007. Alfalfa living mulch advances biological control of soybean aphid. Environmental Entomology 36, 416-424.

Shadbolt, A.A.K., 2005. 'Greening Waipara': Viticulturist's Attitudes and Practices Associated with a Region-Wide Ecological Restoration Scheme. BSc (Honours) Dissertation Lincoln University, Christchurch, New Zealand.

Thomas, M.B., Wratten, S.D., Sotherton, N.W., 1991. Creation of 'island' habitats in farmland to manipulate populations of beneficial arthropods: predator densities and emigration. Journal of Applied Ecology 28, 906-917.

Vanclay, F., Lawrence, G., 1994. Farmer rationality and the adoption of environmentally sound practices; a critique of the assumptions of traditional agricultural extension. European Journal for Agricultural Education and Extension 1 (1), 59-90.

Vosti, S.A., Witcover, J., Oliveira, S., Faminow, M., 1998. Policy issues in agroforestry: technology adoption and regional integration in the western Brazilian Amazon. Agroforestry Systems 38 (1/3), 195-222.

Warner, K.D., 2007. The quality of sustainability: agroecological partnerships and the geographic branding of California winegrapes. Journal of Rural Studies 23, 142-155. 